American Journal of Applied Sciences 6 (7): 1321-1326, 2009

ISSN 1546-9239

(C) 2009 Science Publications

\title{
Studying the Effects of Non-Tariff Barriers on the Export of the Main Agricultural Products of Iran
}

\author{
${ }^{1}$ Z. Ardakani, ${ }^{2}$ S. Yazdani and ${ }^{3} \mathrm{O}$. Gilanpour \\ ${ }^{1}$ Department of Agricultural Economics, Islamic Azad University, \\ Science and Research Branch, Tehran, Iran \\ ${ }^{2}$ Department of Agricultural Economics, University of Tehran, Karaj, Iran \\ ${ }^{3}$ Department of Agricultural Planning, Economics Researchers Institute, Tehran, Iran
}

\begin{abstract}
Problem statement: As trade agreements decrease tariffs throughout the world, other barriers to trade emerge. These Non-Tariff Barriers (NTBs) can be just as troublesome as tariffs for exporting countries. $\mathrm{NTB}_{\mathrm{s}}$ include any of a number of hindrances that restrict the ability of companies to export. $\mathrm{NTB}_{\mathrm{s}}$ may now have a greater impact on trade than tariffs. Approach: In contrast with previous research, we used a gravity model to estimate the trade effect of non-tariff barriers imposed by importer countries on pistachios, raisins and shrimp exported by Iran. Results: NTBs had a negative impact on pistachio and shrimp exports and their effect was greater than that of tariffs; raisin exports were unaffected by NTBs. Conclusion/Recommendations: The export and the world demand for agricultural products increasing focusing on quality, packaging, labeling and standards of products. Policy makers in countries that export agricultural products, such as Iran, must consider these characteristics when designing their programs. Therefore, if Iran builds up-to-date production systems, it will increase its exports of agricultural products.
\end{abstract}

Key words: Pistachio, raisin, shrimp, non-tariff barriers, tariff, gravity model, tariff equivalent, Iran

\section{INTRODUCTION}

In all developed and newly industrialized countries, growth of trade is an indicator of development. Therefore, the export of commodities plays a predominant role in the economy of developing countries. For this reason, most countries have adjusted the structure of their foreign trade programs.

Because tariffs on imports of commodities have been reduced to relatively low levels in many countries due to cyclical rounds of multilateral trade negotiations, researchers have become increasingly interested in the extent to which existing NTBs might distort and restrict international trade. Some trade restrictions may be necessary for countries to ensure the safety of the food supply and the health of plants, animals and the environment. However, sometimes governments go beyond what is necessary to protect domestic industries. Hillman $^{[8]}$ noted that countries can adapt policies to protect the welfare of their citizens, but the purpose of these measures must be to contribute to a legitimate domestic objective and regulations must be applied equally to domestically produced products and imports. Otherwise, the policies mainly protect domestic industries.
When considering NTBs, it is interesting to ask why governments might prefer them over tariffs. Deardorff and Stern ${ }^{[3]}$ suggested the following possible explanations: institutional constraints, such as those built into the General Agreement on Tariffs and Trade (GATT)/WTO rules and into national constitutions that limit the use of tariffs; the roles of firms and workers in influencing the choice of policies; considerations of reaction to or retaliation against the policies of trading partners and uncertainty about the ways in which different policies may perform. Deardorff and Stern favored the last of these explanations insofar as governments perceive that tariffs will not work effectively in reducing imports.

Baldwin ${ }^{[1]}$ defined a "non-tariff distortion" as "any measure (public or private) that causes internationally traded goods and services, or resources devoted to the production of these goods and services, to be allocated in such a way as to reduce potential real world income." Hillman ${ }^{[7]}$ defined NTBs as "any governmental device or practice other than a tariff which directly impedes the entry of imports into a country and which discriminates against imports, but does not apply with equal force on domestic production or distribution."

Corresponding Author: Z. Ardakani, Department of Agricultural Economics, Islamic Azad University, Science and Research Branch, Tehran, Iran 
Lloyd $^{[10]}$ analyzed the concept of a regional "single market," defining a single market as one in which the law of one price prevails, "allowing for transport and other transport costs which prevent perfect arbitrage," as a result of "the removal of all border and non-border restrictions on commodity trade and the harmonization of commodity taxes and other measures which affect access to markets." Mahe's ${ }^{[11]}$ defined an NTB as a restriction other than a tariff that leads to a decrease in world welfare and Thornsbury et al. ${ }^{[13]}$ endorsed Hillman's definition and also included standards of identity, measure and quality, SPS measures and packaging measures.

A wide variety of NTBs exist. Countries must notify their non-tariff measures. These notifications are collected and analyzed by the UNCTAD, which distinguishes between the following seven broad categories of measures:

- Para-tariff measures (customs surcharges, additional charges, internal taxes levied on imports)

- Price control measures (administrative pricing, Voluntary Export Restraints, anti-dumping, countervailing measures)

- Finance measures (advance payment requirements, multiple exchange rates, transfer delays)

- Automatic licensing measures (automatic license, prior surveillance)

- Quantity control measures (non-automatic licensing including prior authorizations, quotas, prohibitions, export restraint arrangements, enterprise specific restrictions)

- Monopolistic measures (single channel for imports, compulsory national services)

- Technical measures (technical regulations, preshipment inspection, special custom formalities, obligation to return used products, obligation of recycling)

The export of agricultural products is a very important part of the non-oil commodities of Iran. Thus, it is important to determine what problems face the export of these agricultural products. Although Iran is observer membership of World Trade Organization (WTO), it benefits from Generalized System of Prefaces (GSP) and Most Favored Nation (MFN) tariffs. Therefore, Non-Tariff Barriers (NTBs) represent one of the main problems confronting the export of Iran's agricultural products.

Pistachios, raisins and shrimp are three main export products of Iran's agricultural sector. Pistachios are the second ranked non-oil export. Among fishery products, shrimp is the second greatest exportable good. Iran is the largest producer of pistachios and one of the major producers of raisins and shrimp, but it has the potential to produce more of these products. In addition, many countries have an unused import capacity for these commodities. Therefore, this study analyzes the impact of NTBs imposed by countries importing these goods from Iran on the trade flow of these products.

\section{MATERIALS AND METHODS}

The literature provides different measures for identifying NTBs to trade and for estimating their impact. We have classified these measures into four groups:

Frequency and coverage type measures: The frequency index only accounts for the presence or absence of an NTB. This index does not provide any information about the relative value of the affected products. This could be acquired through the coverage index. Because the detailed information collected by UNCTAD for its database on trade control measures is commodity/sector and country specific, it is possible to construct a variety of measures that indicate the frequency of occurrence of NTBs. Such measures may be un-weighted, or they may be weighted by imports or by production. The number of product categories subject to NTBs is then expressed as a percentage of the total number of product categories in each Harmonized System (HS) group. This is referred to as the frequency ratio.

Price-comparison measures: The effect of any NTB can be gauged in terms of its impact on the domestic price in comparison to some reference price. Because the price impact is a general property of NTBs, such a price comparison can pick up the net effects of all NTBs that are present in a market, without it being necessary for the investigator to identify what those NTB are. Thus, price comparisons have provided the basis for much of the general empirical work that has tried to quantify NTBs and not just identify where they occur. Results of price comparisons can be used in econometric models.

Quantity-impact measures: The shift of the import demand curve due to an NTB can be defined in either the price or the quantity dimension. This suggests that measurement of this shift could be accomplished by looking at quantities of imports as an alternative to looking at prices. The method here of estimating models of trade flows (mainly using gravity equations) 
in which information about NTBs are introduced as explanatory variables. A gravity model can be used to estimate how much trade is foregone because of the border effect.

Welfare-impact measures: Beghin and Bureau ${ }^{[2]}$ discussed methods that can be used to estimate the effects of an NTB on welfare. Such methods include general equilibrium and partial equilibrium models and risk-assessment-based cost-benefit measures.

Beghin and Bureau ${ }^{[2]}$ noted that estimating the trade forgone as a result of NTBs is an alternative approach to capturing the trade impacts of NTBs. Hence, gravity models are well suited to capture the trade effects of NTBs. Moenius ${ }^{[12]}$ and Mahe ${ }^{[11]}$ also stated that the gravity model is one of the most successful and therefore widely used frameworks for empirical analysis of trade flows between countries. The gravity model has some advantages over other similar methods in estimating the trade flows among countries. First, it requires a relatively limited amount of data; hence, it is conducive for application when data are scarce and costly to acquire. Second, as Head ${ }^{[6]}$ noted, theoretical considerations are now fully elaborated and developed for the gravity model. Thus, the model can estimate the effects of protection on the volume of trade. Third, the gravity model is able to contain the trade-enhancing effect of regulations and the distinct forms of NTBs in estimating the trade flows.

Regression variables that are mostly incorporated in a standard gravity equation used to estimate the impacts of NTBs on agricultural export are included in the specific model used in this study, which holds the following functional form:

$$
\begin{aligned}
\ln \mathrm{EX}_{\mathrm{ij}}= & \alpha_{0}+\alpha_{1} \ln \mathrm{GDP}_{\mathrm{i}}+\alpha_{2} \ln \mathrm{GDP}_{\mathrm{j}}+\alpha_{3} \ln \mathrm{POP}_{\mathrm{i}}+\alpha_{4} \ln \mathrm{POP}_{\mathrm{j}} \\
& +\alpha_{5} \ln \mathrm{D}_{\mathrm{ij}}+\alpha_{6} \ln \mathrm{T}_{\mathrm{j}}+\alpha_{7} \ln \mathrm{TE}_{\mathrm{j}}+\varepsilon_{\mathrm{ij}}
\end{aligned}
$$

$\mathrm{Ln}$ is the natural $\log$. For our dependent variable $\left(\mathrm{EX}_{\mathrm{ij}}\right)$, we choose the value of export of country $\mathrm{i}$ (Iran) to country $\mathrm{j}$. GDP $\mathrm{GDOP}_{\mathrm{j}}, \mathrm{POP}_{\mathrm{i}}$ and $\mathrm{POP}_{\mathrm{j}}$ are Iran's GDP, the importing country's GDP, the population of Iran and the population of the importing country, respectively. $\mathrm{D}_{\mathrm{ij}}$ is the distance between Iran and the importing countries. $T_{j}$ and $\mathrm{TE}_{\mathrm{j}}$ are tariff and NTBs of the importing countries.

Like the mass of two bodies, as stated in the law of gravity that determines the force of attraction between them, the Gross Domestic Product (GDP) of the trading countries represents both the productive and consumption capacity that largely determines the trade flow between them. An importing country's GDP is expected to play a significant role in determining the trade flow originating from exporting countries because the importing country's GDP, like the income of the consumer, plays a significant role in determining the demand for the goods originating from exporting countries. An exporting country's GDP also plays a role in determining the productive capacity of the exporting country (i.e., the amount of goods that can be supplied). In the gravity model, an exporting country's GDP is expected to play a relatively less significant role than that of the importing country's GDP in determining the trade flow of goods originating from exporting country.

The impact of population on trade flow is inconclusive. Population may increase trade flow due to an enlarged market size. On the other hand, a large population may also imply low per capita income; hence, it may affect the trade flow between two countries negatively. Distance is another important variable that is used to capture the trade cost between countries. Countries separated by a short distance are expected to trade more than those that lie far apart due to a lower transaction cost.

We added two variables to the gravity model: tariff and non-tariff barriers. An importing country's tariff is expected to reduce trade flow. NTBs is an important variable in our study. The impact of this variable on trade flow is inconclusive. NTBs that increase barriers or raise costs for all suppliers (and consumers) reduce overall trade flows. In the longer term, NTBs may create trade either by stimulating demand or by leading to efficiency gains. A stringent food safety requirement, for example, may effectively prohibit imports from some countries, cause trade to be diverted to those countries that can comply and have the overall impact of reducing trade. However, those countries with up-todate production systems may actually be able to increase their exports.

We obtained the proxy of NTBs using a basic formula (adapted from Linkins and Arce ${ }^{[9]}$ ).

$\mathrm{TE}$ is defined as the ad valorem tariff equivalent of the NTBs:

$\mathrm{TE}=\left(\mathrm{P}_{\mathrm{d}} / \mathrm{P}_{\mathrm{w}}\right)-(1+\mathrm{t}+\mathrm{d})$

Where:

$\mathrm{P}_{\mathrm{d}}=$ The domestic price, net of wholesale and retail margins

$\mathrm{P}_{\mathrm{w}}=$ The world price, net of wholesale and retail margins

$\mathrm{t}=$ The ad valorem tariff equivalent

$\mathrm{d}=$ The ad valorem international transport margin 
The prices of Iranian pistachios, raisins and shrimp in the domestic markets of importing countries have been unavailable. Therefore, we used the FOB price instead of the domestic price. The FOB price is the invoice price received by an exporter for the good from the importing country, exclusive of transport costs and export tax, if any. Because the FOB price excludes the transportation costs and tariffs, it is eliminated in the second set of parentheses in the Eq. 2.

So:

$$
\mathrm{TE}=\mathrm{P}_{\mathrm{f}} / \mathrm{P}_{\mathrm{w}}
$$

where, $\mathrm{P}_{\mathrm{f}}$ is the FOB price.

Data for GDP and population of all countries were obtained from the World Bank. The trade flows of pistachios, raisins and shrimp from Iran to the importing countries were obtained from the database of Iran's Customs Administration. The distances were extracted from the CEPII database and were calculated as the sum of the distances between the biggest cities of both countries, weighted by the share of the population living in each city. Data for tariffs were obtained from the WTO. FOB and world prices were obtained from Iran's Customs Administration and Food and Agricultural Organization (FAO), respectively. All values of GDP and prices are expressed in US\$. The data were deflated using the countries' Consumer Price Index (CPI), which was obtained from FSI. All data for all variables included in the study are from 1996-2005.

\section{RESULTS}

In this study, we investigated the trade flow of three important products of Iran: Pistachios, raisins and shrimp. For 1996-2005, the major importers of pistachios from Iran were Germany, the United Arab Emirates, Hong Kong, Russia, Turkey, Italy, Spain, Syria and India. During this period, Iranian raisins were exported to the United Arab Emirates, Russian, Ukraine, Pakistan, Germany, Canada, Poland, the United Kingdom and Turkey. Shrimp were exported from Iran to Spain, the United Arab Emirates, Japan, the United Kingdom, Portugal and Italy. The shares of these countries are shown in Table 1.

We now present our estimation results. We used a pooled model to analyze the panel data. Table 2 lists the results of the models.

The classical econometric problems of the models have been tested. Serial correlation was not found in the models, as indicated by the Durbin Watson value. White heteroskedasticity consistent standard errors and covariance also were used in the models. Stationary was checked in the models as well.
Table 1: The share of major countries importing goods from Iran

\begin{tabular}{|c|c|c|c|c|c|}
\hline \multicolumn{2}{|l|}{ Pistachio } & \multicolumn{2}{|l|}{ Raisin } & \multicolumn{2}{|l|}{ Shrimp } \\
\hline Country & $\begin{array}{l}\text { Share } \\
(\%)\end{array}$ & Country & $\begin{array}{l}\text { Share } \\
(\%)\end{array}$ & Country & $\begin{array}{l}\text { Share } \\
(\%)\end{array}$ \\
\hline Germany & 22.2 & $\begin{array}{l}\text { United Arab } \\
\text { Emirates }\end{array}$ & 21.5 & Spain & 38.4 \\
\hline $\begin{array}{l}\text { United Arab } \\
\text { Emirates }\end{array}$ & 21.9 & Russian & 15.4 & $\begin{array}{l}\text { United Arab } \\
\text { Emirates }\end{array}$ & 24.0 \\
\hline Hong Kong & 12.3 & Ukraine & 10.6 & Japan & 6.5 \\
\hline Russian & 4.6 & Pakistan & 6.8 & $\begin{array}{l}\text { United } \\
\text { Kingdom }\end{array}$ & 4.0 \\
\hline Turkey & 4.0 & Germany & 5.2 & Portugal & 3.6 \\
\hline Italy & 3.6 & Canada & 4.8 & Italy & 3.2 \\
\hline Spain & 3.5 & Poland & 4.3 & - & \\
\hline Syria & 2.4 & $\begin{array}{l}\text { United } \\
\text { Kingdom }\end{array}$ & 2.4 & - & \\
\hline India & 2.0 & Turkey & 1.4 & - & \\
\hline Total & 76.5 & & 72.4 & & 79.7 \\
\hline
\end{tabular}

Table 2: The results of the estimations

\begin{tabular}{|c|c|c|c|}
\hline \multirow[b]{2}{*}{ Variable } & \multicolumn{2}{|c|}{ Dependent variable: $\mathrm{Ln}_{\mathrm{EX}} \mathrm{ij}$} & \multirow[b]{2}{*}{ Shrimp } \\
\hline & Pistachio & Raisin & \\
\hline$\overline{\mathrm{C}}$ & $\begin{array}{c}389.250 \\
(147.380)\end{array}$ & $\begin{array}{r}-36.970 \\
(7.460)\end{array}$ & $\begin{array}{l}-36.130 \\
(25.190)\end{array}$ \\
\hline Ln GDP & - & - & $\begin{array}{r}2.520 * * \\
(0.977)\end{array}$ \\
\hline $\operatorname{Ln} \mathrm{GDP}_{\mathrm{j}}$ & $\begin{array}{c}0.810^{*} \\
(0.105)\end{array}$ & $\begin{array}{c}0.120^{*} \\
(0.036)\end{array}$ & $\begin{array}{l}-4.500^{*} \\
(1.334)\end{array}$ \\
\hline Ln $\mathrm{POP}_{\mathrm{i}}$ & $\begin{array}{c}20.700 * * \\
(8.190)\end{array}$ & $\begin{array}{l}3.040^{*} \\
(0.411)\end{array}$ & - \\
\hline $\operatorname{Ln} \mathrm{POP}_{\mathrm{j}}$ & $\begin{array}{c}0.420^{*} \\
(0.105)\end{array}$ & - & $\begin{array}{c}6.250^{*} \\
(1.824)\end{array}$ \\
\hline $\operatorname{Ln} D_{i j}$ & $\begin{array}{l}.1 .780 * \\
(0.236)\end{array}$ & $\begin{array}{l}0.680^{*} \\
(0.033)\end{array}$ & - \\
\hline $\operatorname{Ln} T_{j}$ & $\begin{array}{l}.0 .110^{*} \\
(0.028)\end{array}$ & $\begin{array}{l}0.079^{*} \\
(0.005)\end{array}$ & $\begin{array}{l}0.340 * \\
(0.082)\end{array}$ \\
\hline $\operatorname{Ln} \mathrm{TEj}$ & $\begin{array}{l}-2.240 * * \\
(1.027)\end{array}$ & $\begin{array}{c}1.130^{*} \\
(0.042)\end{array}$ & $\begin{array}{r}-0.560 * * \\
(0.393)\end{array}$ \\
\hline R-squared & 0.990 & 0.990 & 0.970 \\
\hline Adj R-squared & 0.990 & 0.990 & 0.970 \\
\hline Durbin-watson & 1.750 & 1.570 & 1.840 \\
\hline F Stat. & 3012.230 & 122979.000 & 441.670 \\
\hline
\end{tabular}

The GDP of Iran was insignificant in the estimation of the pistachio equation. The coefficients of the other variables were significant and had the expected sign. In the equation for raisins, all estimated coefficients were significant except GDP and POP of Iran. POP of Iran and distance variables were not significant in the equation for shrimp.

\section{DISSCUSION}

The results of the estimations show that the tariff and non-tariff barriers adopted by the importing countries are significant factors that affect the trade flows. The elasticity of NTBs for pistachio and shrimp 
were 2.24 and 0.56 , respectively, which implies that a percent increase in the NTBs would decrease the pistachio and shrimp trade flow by 2.24 and $0.56 \%$. Our results largely confirm the finding of previous studies. Moenius $^{[12]}$ reported that country-specific product and process standards of importers reduce imports in the agricultural sector. Fontagne et al. ${ }^{[5]}$ focused on Sanitary and Phyto Sanitary (SPS) and Technical Barriers to Trade (TBT) measures. They showed that these measures negatively influence bilateral trade of cut flowers and of processed foods such as beverages. The elasticity of the tariff variable for pistachios and shrimp was 0.11 and 0.34 , respectively, which suggests that a percent increase in the tariffs would decrease the pistachio and shrimp trade flow by only 0.11 and $0.34 \%$. This shows that NTBs have reduced the export of these products to a greater extent than would tariffs. Disdier, Fontagne and Mimouni ${ }^{[4]}$ found that SPS and TBT measures have a negative impact on OECD imports and that their effect is higher than that of tariffs. For raisins, the elasticity of NTBs was 1.13, implying that NTBs have not affected the trade flow of this product negatively. Disdier, Fontagne and Mimouni $^{[4]}$ also investigated the effect of NTBs on agricultural sub sectors of OECD importers. Their estimated coefficient of NTBs for some sectors was positive. This suggests that not all SPS and TBTs in agriculture are protectionist devices. The effect of tariffs on the export of raisins was negative and negligible.

\section{CONCLUSION}

Thus, our results suggest the following:

- $\quad$ NTBs negatively impact the trade of pistachio and shrimp products. The most important reasons for the reduced export of these products are SPS and TBT measures. According to WTO rules, countries are allowed to adopt regulations under the SPS and TBT agreements in order to protect human, animal and plant health as well as the environment, wildlife and human safety

- The effect of NTBs is higher than that of tariffs for pistachios and shrimp. This shows that nowadays NTBs are more important than tariffs

- NTBs have not negatively impacted the trade flow of raisins. This result shows that raisins have suitable conditions for export or that the main importing countries do not have hard standards and regulations

The export and the world demand for agricultural products is increasing focusing on quality, packaging, labeling and standards of products. SPS and TBT agreements consist of these characteristics. Therefore, policy makers in countries that export agricultural products, such as Iran, must consider these characteristics when designing their programs. These measures have not yet been imposed on the main agricultural exports of Iran. Therefore, the countries that import pistachios, raisins and shrimp, especially Europe Union members, have reduced their imports from Iran. In short, if Iran builds up-to-date production systems, it will increase its exports of agricultural products.

\section{REFERENCES}

1. Baldwin, R., 1970. Non-Tariff Distortions in International Trade. Brookings Institution, Washington, DC., pp: 210.

2. Beghin, J.C. and B.J. Christophe, 2001. Quantification of sanitary, phytosanitary and technical barriers to trade policy analysis. Working paper 01-WP 291.

http://ideas.repec.org/p/ias/fpaper/01-wp291.html

3. Deardorff, A.V., 1987. Why do governments prefer nontariff barriers? Proceeding of the CanegieRochester Conference on Public Policy, Jan. 1-1, Elsevier, USA., pp: 191-216. http://ideas.repec.org/a/eee/crcspp/v26y1987ip191216.html

4. Disdier, A., L. Fontagne and M. Mimouni, 2006. The Impact of Regulations on Agricultural Trade: Evidence from SPS and TBT Agreements. http://www.econ.iastate.edu/calendar/papers/Disdie r_ISU.pdf

5. Fontagne, L., M. Mimouni and J.M. Pasteels, 2005b. Estimating the impact of environmental SPS and TBT on international trade. Integrat. Trade J., 22: 7-37. http://papers.ssrn.com/sol3/papers.cfm?abstract_id $=1260862$

6. Head, K., 2000. Gravity for beginners. presented at rethinking the line. Proceeding of the Canada-US Border Conference, Oct. 22-22, Vancouver, British Columbia, pp: 179-232.

7. Hillman, J.S., 1991. Technical Barriers to Agricultural Trade. Westview Press, Boulder, Colo USA., ISBN: 08-133-81304, pp: 199.

8. Hillman, J.S., 1996. Non Tariff Agricultural Trade Barriers Revisited. Working Paper no. 96-2. International Agricultural Trade Research Consortium.

9. Linkins, L.A. and H.M. Arce, 2002. Revised, estimating tariff equivalents of non tariff barriers. Working paper 94-06-A(r). http://hotdocs.usitc.gov/docs/pubs/research_workin g_papers/EC199406AR.pdf 
10. Lloyd, P., 1996. The Changing Nature of RTA. In: Regional Integration and Asia Pacific, Bora, B. and C. Findlay (Eds.). Oxford University Press, Melbourne, ISBN: 0195536355, pp: 260.

11. Mahé, L.P., 1997. Environment and quality standards in the WTO: New protectionism in agricultural trade? A European perspective. Eur. Rev. Agric. Econ., 2: 480-503.

12. Moenius, J., 2004. Information versus product adaptation: The role of standards in trade. International business and markets research center working paper no. 1, Northwestern University. http://papers.ssrn.com/sol3/papers.cfm?abstract_id $=608022$
13. Thornsbury, S., D. Roberts, K. Deremer and D. Orden, 1999. A First Step in Understanding Technical Barriers to Agricultural Trade. In: Food Security, Diversification and Resource Management: Refocusing the Role of Agriculture, Peters, G.H. and J. Von Braun (Eds.). Ashgate, Brookfield, VT., pp: 453-465. 